STUDIA NORWIDIANA 38:2020

DOI: https://doi.org/10.18290/sn.2038-8

MAGDALENA KOWALSKA

\title{
KOLUMNA NA PLACU VENDÔME A PRZEMIJAJACCA POSTAĆ ŚWIATA STAROŻYTNEGO RZYMU W PISMACH CYPRIANA NORWIDA
}

\section{MOTYW I PYTANIE BADAWCZE DO NIEGO}

O tym, że kolumna to jeden „z dwóch ulubionych przez Norwida składników architektury klasycznej"1 przekonywała praca Kazimierza Wyki z 1948 r. $C y$ prian Norwid: poeta i sztukmistrz. Niniejszy artykuł dotyczy literackich przedstawień kilku przykładów takiego upodobania: rzymskich kolumn Trajana i Marka Aureliusza oraz przede wszystkim paryskiej kolumny z placu Vendôme ${ }^{2}$, a zatem zabytków, co do których warto przypomnieć rzecz podstawową są to kolumny triumfalne. Z szerokiego kręgu znaczeń jednostki słownikowej „kolumna”: słup, posąg, pionowa podpora wspierająca część budowli, która służy również jako podstawa pomnika lub pomnik - należy wybrać te synonimiczne do statuy, aby zrozumieć funkcje pełnione przez ten typ elementu architektury miejskiej. Poetycki opis kolumny triumfalnej stanowi bowiem inny rodzaj obrazu niż przedstawienie kolumnady, uwypuklające pluralizm kolumn, a także niekiedy ich rozmieszczenie na planie budynku, które spotykamy np. w przedmowie do Quidama: „do tego kościoła, co w kwadracie kolumn świątyni starożytnej jako gołąb w rozłamanej klatce przestawa" (DW III, 119) lub we fragmencie „dalej kolumn rząd” (PWsz I, 98) z wiersza Z listu (do Wtodzimierza Lubieńskiego). Określenie: „klatka”, tak jak i „rząd”, przywodzi na myśl regularne odstępy między kolumnami. Opozycja wielość-pojedynczość nie wyczerpuje jednak aspektu różnicującego przesłanie kolumny triumfalnej od wymowy

${ }^{1}$ K. WYKA, Cyprian Norwid: poeta i sztukmistrz, Kraków 1948, s. 100.

${ }^{2} \mathrm{~W}$ treści artykułu będę stosować nazwę: kolumna Vendôme, choć nie jest to określenie ścisłe. Kolumnę umieszczoną na placu Vendôme nazywano kolumną Austerlitz, Zwycięstwa, kolumną Wielkiej Armii, por. A. TARDIEU, La Colonne de la Grande Armée d'Austerlitz ou de la Victoire, monument triomphal érigé en bronze sur la Place Vendôme de Paris, Paris 1822, s. 12. Używa się jednak w języku francuskim nazwy „la colonne Vendôme”. 
odmiennego jej typu, ponieważ ten rodzaj obrazu, który reprezentuje kolumna triumfalna wymaga narzędzi interpretacyjnych innych także niż te potrzebne do analizy poetyckiego widoku jednej kolumny. Zazwyczaj u Norwida jest ona jedyną zachowaną pośród wielu, a zatem upodabnia się do triumfalnej przez swoją pojedynczość, ale odmiennie od niej ona uwypukla przez to raczej znaczącą nieobecność pozostałych kolumn: ,greckiej kolumny, / Na brzegu morskim oszklonej - tak żal mi!" (PWsz I, 98; ponownie Z listu (do Włodzimierza Lubieńskiego)), bądź też akcentuje przypadkowe rozmieszczenie osamotnionych świadków dawnej wielkości, jak na przykład w Quidamie: „w przypowieści tej mojej, [...] lubo nie ma arków połamanych i rozrzuconych kolumn, nie mniej smętny, [...] krajobraz ruin się przedstawia" (DW III, 119).

Pytanie, które towarzyszy mi w analizie pism Norwida, ustanawiam opierając się na założeniu pochodzącym z wykładów Estetyki Georga Wilhelma Friedricha Hegla spisanych w notatniku - jednym spośród kilku wędrujących w tej epoce po Europie - należącym do Victora Cousina. Przedstawiając cele architektury klasycznej, autor pisał, że trzeba, aby świątynia była przestrzenią zamkniętą $\mathrm{w}$ trzech wymiarach ${ }^{3}$. Zauważał też, że np. piramida podoba się, ponieważ jej szerokość i długość przekonują, że jest ona zdolna unieść (porter) to, co na górze, natomiast jej część najwyższa nie jest przeznaczona do wspierania czegokolwiek, sama będąc wspierana, dlatego zbiega się w jednym punkcie, wierzchołku. Celem zaś tego, co otacza, jest unieść to, co na górze, i stać się łącznikiem z tym, co dookoła. Konstrukcja powinna uwidaczniać ten podwójny cel. W tym miejscu pojawia się inspirujące dla mnie zdanie dotyczące kolumny: L'abstraction du porter pour soi est la colonne. Ideą tego, co wspiera samo siebie (niesie tylko siebie) jest kolumna. Aby utrzymać ciężar budowli, potrzeba wielu kolumn, z kolei aby to, co otacza, stanowiło jedność, konieczne jest ich połączenie ze sobą. Kolumna jednakże jako taka jest ideą tego, co wnosi tylko siebie. Wracając do dzieł Norwida, przypomnijmy, że w Epimenidesie czytamy:

\footnotetext{
${ }^{3}$ G.W.F. Hegel, Esthétique: cahier de notes inédit de Victor Cousin, éd. A.P. Olivier, Paris 2005, s. 107-108: „Le but est que le temple doit être un enclos, une enveloppe”. Następnie analizuje ,forme de cet enclos”: „1) Nous avons un endroit fermé dans les trois dimensions. La muraille enveloppe du côté de la langueur et de la largeur, mais pour la hauteur, le toit peut être horizontal ou oblique. [...] Une pyramide qui va en pointe nous plaît; car si nous voyons une largeur, nous sentons qu'elle est capable de porter; mais si une construction est bâtie dans le sens de la hauteur, la partie supérieure n'a plus la destination de porter. [...] La partie supérieure ne doit qu'être portée; elle doit montrer par sa forme même de ne plus pouvoir porter, c'est-à-dire: elle doit terminer en pointe. 2) Le but est d'entourer; ce but se partage en plusieurs déterminations: porter ce qui est en haut, et joindre ce qui sert à porter et à entourer. Une construction doit montrer chacune de ces deux déterminations dans leur abstraction pour soi. L'abstraction du porter pour soi est la colonne".
} 
„Kolumn wiele, [...] Zbłąkanych kolumn wiele, gmachu gdzieś szukało - ” (DW III, 87). Parafrazując słowa autora Vade-mecum, chcę zatem zapytać, czego szuka kolumna, jeżeli nie jest to gmach, tak jak właśnie dzieje się w przypadku kolumny triumfalnej, co ona niesie, co utrzymuje, co wspiera, czego jest podstawą? Szukam odpowiedzi na ten temat oczywiście w wymiarze symbolicznym, ponieważ na planie rzeczywistym jest ona jasna - są to posągi, które wielokrotnie zmieniano w toku wydarzeń historycznych, gloryfikując wodzów, apostołów, a także panujące dynastie.

\section{„TOUT HÉROS, TOUT GRAND HOMME A CHANGÉ DE PAYS; ROME N'EST PLUS DANS ROME, ELLE EST TOUTE À PARIS" - ŹRÓDŁA INSPIRACJI W MYŚLENIU O PARYŻU JAKO NOWYM RZYMIE}

Motyw kolumny w pismach Norwida można byłoby z powodzeniem zinterpretować przywołując, podobnie jak czynił to Wyka, jej starożytne przykłady, ponadto analizując symbolikę światła w jej otoczeniu czy związek obrazu kolumny z przestrzenią świątyni. Wybór dziewiętnastowiecznej, a więc współczesnej Norwidowi kolumny, jako przedmiotu badania, nie byłby oczywisty, gdyby nie kilka niezaprzeczalnych faktów, wskazujących na wagę tego właśnie paryskiego zabytku - kolumny Vendôme. W warstwie biograficznego odczytania istoty problemu przypomnieć trzeba, że Norwid ogłaszał swój protest przeciwko jej zburzeniu:

Jako członek Towarzystwa Artys[tów] Franc[uskich], kiedy zakładałem protestację przeciw zburzeniu Kolumny Vendôme i kościołów, wypowiedziałem wyraźnie, że zamiast znieważać kapłanów na ulicach i domy Boże plądrować, trzeba OŚWIECAĆ LUD, „car il vous détruira tous les monuments et tous les musées à l'exception de celui de l'Histoire Naturelle" (les singes comprendront les singes). [...] Wtedy pisać nie mogłem więcej nad znak pobieżny, z powodu że gdyby tylko była [1.] moja protestacja przeciw więzieniu duchowieństwa i burzeniu kościołów - 2. druga, przeciw obaleniu Kolumny Vendôme - i 3. proklamacja do rodaków, aby odmówili służb Komunie i tej generacji (po czym dziennik „Temps” był zamknięty), to już trzy [...]. (PWsz IX, 483-484)

Odwołując się do samych tylko tekstów Norwida, można dostrzec, że kilkakrotnie kolumna Vendôme jest przez niego przywoływana, a zarazem najczęściej bywa konfrontowana z rzymskimi elementami architektury starożytnego Rzymu.

\footnotetext{
${ }^{4}$ D. Rowell, Paris: The 'New Rome' of Napoleon I, London-New York 2012, Appendix 1.
} 
Poszukując podpowiedzi, skąd pomysł na takie zestawienie, należy zauważyć, że Piotr Chlebowski słusznie wskazuje na dzieło Constantina François Volneya jako źródło popularności analogii między starożytnym Rzymem i dziewiętnastowieczną Francją ${ }^{5} \mathrm{w}$ epoce, jednak sama idea translatio imperii jest o wiele starsza. Była głoszona w świecie średniowiecznym, a jej rozpowszechnienie zawdzięcza się Chrétienowi de Troyes, który w powieści Cligès (prawdopodobnie z 1176 r.) opowiadał, że chwała rycerstwa (chevalerie) oraz kapłaństwa (clergie) przeszła z Grecji do Rzymu, a następnie do Francji ${ }^{6}$. Wtórowało tym głosom wielu średniowiecznych francuskich kronikarzy, w tym Guillaume de Nangis, który uznał, że tak sapientia, jak i militia z Grecji przybyły do Paryża, aby połączyć się w trzeci jeszcze element, fides ${ }^{7}$.

W ideę translatio imperii wpisywały się także plany, według których kolumnę Vendôme miałby wieńczyć posąg Karola Wielkiego ${ }^{8}$. Czego gwarancją stałoby się dla pomysłodawców odwołanie się do tego toposu? Podstawowym jego składnikiem było pojęcie imperium, a zatem, jak zauważa Rebecca Comay, wyznawcom tej koncepcji zależało na nadaniu genealogii podbojom terytorialnym, rozciągnięciu wymiaru czasowego na ekspansję przestrzenną ${ }^{9}$. Imperium nie można zniszczyć, ono nie ginie, jedynie jego centrum, tak jak i kształt całości, przenosi się i przemienia. Ci, którzy współtworzą nowe imperium, pragną pozyskać splendor poprzedników także po to, aby ich zastąpić w tej pełnej zaszczy-

${ }^{5}$ Zob. N.M. AlveY, Strange Truths in Undiscovered Lands: Shelley's Poetic Development and Romantic Geography, Toronto 2009, s. 34: „Volney's review of world history reflects the old concept of the translatio imperii, which was revived as the idea of progress in the eighteenth century. [...] A universal revolution starts in France, and Volney hopes that it will spread all over the world”. D. SKILTON, Tourists at the ruins of London. The Metropolis and the Struggle for Empire, „Cercles” 17(2007), s. 105: „Volney's project is to convince legislators that reason can produce ideal schemes of government which will enable states and empires to avoid the errors of the past, among them superstition and religious belief general, and so endure indefinitely, and in the 'Avertissement' to Les Ruines he refers directly to the Revolution as providing the legislator able to put such a programme into effect".

${ }^{6}$ Ch. DE Troyes, Cligès, Berlin 2006, s. 26.

${ }^{7}$ J.W. BALdwin, Masters at Paris from 1179 to 1215, [w:] Renaissance and Renewal in the Twelfth Century, edited by R.L. Benson, G. Constable, C.D. Lanham, Toronto 1991, s. $162-163$.

${ }^{8}$ D. Rowell, Paris: The 'New Rome' of Napoleon I, s. 70.

${ }^{9}$ R. COMAY, Mourning Sickness: Hegel and the French Revolution. Cultural Memory in the Present, Stanford 2010, s. 15: „The medieval ideology of translatio imperii had inextricably connected genealogical transmission to geographical conquest, temporal extension to spatial expansion: empire is defined as the uninterrupted relay of dynastic legitimacy and authority, without leakage or loss of symbolic potency, across territorial lines". 
tów roli ekspansjonisty ${ }^{10}$. Napoleon pragnął przenieść kolumnę Trajana do Paryża - dopiero przekonanie go, że akt ten zniszczyłby zabytek, zapobiegło takim planom. Warto o tym pamiętać, analizując słowa Norwida o paryskiej „kopii” rzymskiego monumentu.

Paryska kolumna Vendôme w świetle kultury antycznego Rzymu ujawnia się $\mathrm{u}$ Norwida w trzech odmiennych odsłonach wierszowanych: w liryku Vendôme, gdzie w przestrzeni nokturnalnej Paryża dochodzi do spotkania Juliusza Cezara z "Cezarem drugim świata po-rzymskiego", Napoleonem, ponadto w utworze Odpowiedź do Włoch... (Fraszka), w którym jedna nazwa odnosi się do dwóch desygnatów: dowiadujemy się, że jest Rzym i „ten” Rzym, czyli Paryż, w którym wznosi się taka sama kolumna Trajana, tylko „przebrązowana, na Napoleona wielkie imię". W tych świadectwach zainteresowania kolumną można odczytać znaki kontynuacji dziedzictwa rzymskiego w nowożytnej Francji. Trzecim sygnałem jest część Listy z poematu Szczesna, w której miasta Paryż i Rzym nie są ze sobą utożsamione, nie mówi się nawet o ich podobieństwie, ale przedstawione obok siebie, jako kolejne punkty na mapie podróży bohatera, wzajemnie się oświetlają i, jak postaram się wykazać, w ich opisie można także zauważyć elementy topiki kolumny, choć ta rzeczywista pojawia się tylko jedna - na placu Vendôme.

\section{ODSŁONA PIERWSZA.
„L'ÉPOQUE DE GLOIRE”11 CZY „TOUS CES FANTÔMES DE GLOIRE” ${ }^{\text {? }}$ ?}

Słowa Napoleona z wiersza Vendôme podpowiadają, że można w jego przesłaniu spodziewać się elementów wykładni kolumny, padają one jednak dopiero w środkowej części wiersza i sugerują bezradność osoby mówiącej w wierszu wobec odbiorcy:

ale komuż kazać mam o sile Tryumfalnymi mierzonej kolumny?... ${ }^{13}$

${ }^{10}$ D. BATtLES, The Medieval Tradition of Thebes: History and Narrative in the „Roman de Thèbes, Boccaccio, Chaucer, and Lydgate, Routledge 2004, s. 23: „In a nutshell, translatio imperii bespeaks a desire to share in the authority of the ancients while replacing them".

${ }^{11}$ T. Labourieu, La Colonne Vendôme, roman historique, Paris 1872, s. 3.

${ }^{12}$ V. Hugo, À la colonne, w: IDEM, CEuvres complètes. Poésie, Paris 1834, s. 334.

${ }^{13}$ C. NORWID, Vendôme (PWsz I, 110). 
W tym utworze mamy do czynienia $\mathrm{z}$ jedną tylko kolumną, paryską, mimo to Juliusz Cezar w poetyckim obrazowaniu znajduje się na tym samym poziomie co francuski cesarz. Dotarł jednak na to miejsce - miejsce, na które Napoleona wyniosła kolumna - według innego wektora ruchu:

Cień Julijusza, w złotawej klamidzie,

Jakoby chmura popod księżyc idzie,

By śmiertelnemu, co pogląda z ziemi,

Wydał się światła-szyby rozlanemi,

I u kolumny zawisnąwszy szczytu $[\ldots]^{14}$.

Aspekt zniwelowania różnicy między rozmówcami uwydatniają badacze: Anna Kadyjewska zauważyła, że Juliusz Cezar i Napoleon spotykają się w połowie drogi i są zharmonizowani „lotnością duchów i brązu ciężarem” ${ }^{15}$, podobna metafora ujawniła się również w artykule Jacka Lyszczyny, który podkreślał, że: „Protagoniści tej niezwykłej sceny, którzy spotykają się pomiędzy niebem a ziemią, sami niejako są w drodze" różnic między postaciami, odnoszących się po pierwsze do ich relacji do statyczności-dynamiki oraz po drugie dotyczących punktu wyjściowego ich wędrówki. W poetyckiej metaforze początku wiersza uwagę przykuwa gra światła, ale niemniej ważny okazuje się czasownik w czasie teraźniejszym, określający czynność Juliusza Cezara za pomocą przepływu obłoku, który wskazuje na proces:

\footnotetext{
${ }^{14}$ Tamże, s. 108

${ }^{15}$ A. KADYJEWSKA, Norwidowskie rozmowy umartych - dialog postaci i epok, w: Liryka Cypriana Norwida, red. P. Chlebowski, W. Toruń, Lublin 2003, s. 289.

${ }^{16}$ J. LySZCZYNA, Dumanie na placu Vendôme. Norwid wobec romantycznego kultu Napoleona, w: Norwid - spotkania kultur, red. E. Chlebowska, Lublin 2015, s. 307. W innym miejscu swojego artykułu badacz ten zawiera stwierdzenie, że dialog ,poeta umieszcza jednak nie na Polach Elizejskich, ale w przestrzeniach nieba”, co miałoby decydować o „chrześcijańskim charakterze całej wizji, a więc i treści toczącego się w górze dialogu" (tamże). Bardziej przekonało mnie określenie ,pomiędzy niebem a ziemią”, dlatego też to je zacytowałam w tekście głównym. Znakiem złączenia z żywiołem ziemi w wierszu jest choćby kolumna, która pozwala, odejmując trochę „niebiańskości” nakreślonej tam wizji, na zderzenie tej rozmowy w zaświatach z imaginarium urbanistycznym. Zabytki, budowle, kolumny - ożywają podczas snu mieszkańców miasta. W pierwszej części ody do kolumny Vendôme Hugo dowiadujemy się o częstych spotkaniach poety z kolumną w szczegółowo zaaranżowanej przestrzeni: są to wieczory, kiedy noc zmusza do ucieczki księżyc i porusza niebem, wstrząsając gwiazdami: „Que de fois, tu le sais, quand la nuit sous ses voiles / Fait fuir la blanche lune ou trembler les étoiles" (V. Hugo, À la colonne, s. 335). W wierszu Norwida księżyc na początku - choć tylko w metaforze - znika, wschodzi zaś przy jego końcu - być może on także jest jednym z symboli innej rzeczywistości pozwalającej na to spotkanie.
} 
„idzie”, oraz jego zwieńczenie: „zawisnął”. Ruchu księżyca, czy to wokół Ziemi, czy wokół własnej osi, nie dostrzeże się okiem przechodnia, pozostaje on zatem dla „śmiertelnika” statycznym elementem nocnego nieba, z kolei pęd chmur gnanych wiatrem jest powszechnie obserwowalnym zjawiskiem. Juliusz Cezar jest zatem postacią $\mathrm{w}$ ruchu, dopóki nie zatrzyma się w pozornym bezruchu, będąc zawieszonym - tak jakby coś wiązało go jednak z niebem ${ }^{17}$, Napoleona zaś utrzymuje na tej wysokości kolumna trwale osadzona na ziemi. Warto rozważyć, czy to zakorzenienie ujawnia się w treści wypowiadanych przez postać słów, w sposobie ujmowania rzeczywistości przez Napoleona. Początkowo może się wydawać, że wyważono postacie obydwu władców, wyposażając ich i w lotność „duchów” (oczywista właściwość postaci w dialogu umarłych, co uwypukla także późniejsze określenie, że są „obadwaj w błękit jeden obwinieni” nieśmiertelności), i „ciężar brązu” - w tym punkcie z kolei może się pojawić pytanie, jak ta cecha realizowana jest w odniesieniu do Juliusza Cezara? Dlatego ten fragment należałoby rozumieć inaczej niż w ten sposób, że każda z tych właściwości przynależna jest zarazem obu postaciom: to Juliusz Cezar charakteryzuje się „lotnością duchów”, a Napoleon „brązu ciężarem”, są natomiast „porozumieni", gdyż dzięki tym cechom mogą odbyć wspólnie rozmowę. Antycypując analizę tematu ich wypowiedzi, należy zaznaczyć, że Napoleon odnosi się do ludzkich prymarnych potrzeb, takich jak potrzeba pożywienia: „Godziny jednej nie przeżyłeś w głodzie”, opowiada o poczucie niespełnienia (,w ducha pragnieniu"), dzieli się doświadczeniem wojennym ingerującym w cielesność człowieka („Nie czułeś mieczy, gdy się krwią wilgocą”).

W tym kontekście po raz pierwszy pojawia się w wyznaniu Napoleona słowo „moc", nalega on, iż zna to słowo nie tylko w takim wymiarze, jak nabywa się leksykę w procesie uczenia się, lecz jest to dla niego słowo wcielone, przekute: „na stal i fortel, i na spiż”. Jak zauważa Napoleon, Juliusz Cezar, choć panujący

\footnotetext{
${ }^{17}$ Kadyjewska stwierdziła, że mara Cezara „wydaje się wznosić ku szczytowi kolumny jak chmura, skrywając się jednocześnie przed wzrokiem niepożądanego obserwatora $\mathrm{z}$ dołu” (Norwidowskie rozmowy umarlych, s. 280-281). W mojej optyce ruch postaci Cezara odbywa się raczej z góry ku dołowi, poprzez porównanie z chmurą, która „popod” księżyc idzie. Zainspirowana dialogiem kolumn w języku francuskim (F. LEBCEUF, Dialogue entre la colonne Vendôme et la colonne de Juillet, Paris 1843), postanowiłam sprawdzić, czy byłoby możliwe zainscenizowanie przez Norwida takiej rozmowy - dziewiętnastowieczni mogli w Paryżu podziwiać dwa posągi Juliusza Cezara, obydwa w Jardin des Tuileries: dłuta Nicolasa Coustou (od 1722, po ukończeniu w Luwrze) oraz Ambrogia Parisiego (od 1800, kopia w muzeum w Luwrze). Rozmowy pomników reprezentuje w poezji francuskiej także utwór Nostalgies d'obélisques Theophile'a Gautiera, o którym w kontekście paraleli Norwid-Gautier pisał Maciej Żurowski, Między renesansem i awangarda. O literaturze europejskiej z perspektywy komparatysty, Warszawa 2007, s. 157-158.
} 
już w I wieku przed Chrystusem, jest „młodszy mocą czasów” niż Zbawiciel. Moc może stać się zatem przymiotem tak epoki, jak i jej bohaterów. Dyspozytorem takiej władzy nadania mocy jest Bóg, co symbolicznie zostało przedstawione w obrazie burzy, w której moc powraca „piorunowa”, uwidaczniając się na niebie ,poprutym”, w którym można dopatrywać się biblijnego sposobu rozumienia gniewu Bożego (Rz 1, 18). Słowo „moc” powraca po raz kolejny wplecione w pytanie, które rozpoczyna się od westchnienia: „- Ach, moc !... o cieniu!... a nieba odbicie / W sumieniu?!".

Drugim słowem kluczem, które nieodparcie nasuwa się Napoleonowi w jego przemowie, jest epitet „triumfalny”, na którego kluczowość zwróciłam uwagę na początku artykułu w odniesieniu do kolumny. W Vendôme użyto go trzykrotnie, raz tylko dotyczy kolumny, ale i pozostałe przywołania odnoszą się do symboliki antycznego Rzymu imperatorów:

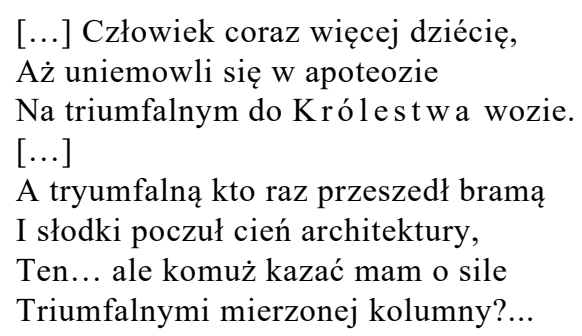

(PWsz I, 110)

Wóz, „brama” (czyli łuk) oraz kolumny - spośród tych trzech elementów wyłącznie dwa zostały użyte w kontekście spodziewanym, to jest $\mathrm{w}$ opisie poczucia spełnienia płynącego z panowania, ekspansji i zdobycia władzy nad ludem, który stawia pomniki ku chwale imperatora. Niektóre aspekty są jednak zaskakujące wóz triumfalny został wykorzystany jako narzędzie drogi człowieka do Królestwa. Każda istota ludzka „uniemowli się”, przekraczając bramy Królestwa Niebieskiego, ale i sztukmistrz (rzeźbiarz) „uniemawla” postacie wielkich mężów, „olbrzymów ziemi”, staną się oni „nieba dziecięciem”, także ci, których kolumny wynosiły na triumfatorów. Wskazując powyżej, że moc może stać się zatem przymiotem tak epoki, jak i jej postaci, korzystałam z Norwidowskiej konstatacji: „Otóż i z mocą stawa się tak samo, / Jako z mężami, z brązy i z marmury”. Moc to siła narodów świata, o których opowiada Napoleon („I one mocy tak się rozmocniły"). Napoleon udowodnił, że rozumie wartość mocy, ale wyznaje też, że to osiągnięcie jej $\mathrm{w}$ takim stopniu, jakie znaczenie nadają tej nazwie ludzie, nie staje się jego celem, gdyż wie, gdzie takiej mocy, „wszech-siły” w ludzkim rozumieniu, jest kres. Po klęsce pojawia się inny triumfator, tak jak 
po epoce Juliusza Cezara nadszedł czas na apogeum wielkości Napoleona (który podpowiada przecież rozmówcy: „ile twe ja byłem dziecię"18), pobojowisko zmienia się w pobojowisko, a „z człeka się wywalcza człowiek”. Element architektoniczny - łuk triumfalny - powraca u kresu tej wizji, podwojony i zwielokrotniony, jako początek i koniec („od łuku bliżej dziś do łuku”), jako symbol wreszcie uniwersalności (,wszech-łuk”), to zakończenie przynosi zarazem jeszcze jedno użycie epitetu „triumfalny”: „,sny prze-triumfalne”.

Ruch na osi pionowej wprowadzony do obrazowania lirycznego Vendôme od początku utworu powraca po pauzie myślowej, która następuje po zakończeniu dialogu postaci, wzbogacony jednak o wymiar poziomy:

\begin{abstract}
Tu się chmurami zakrył szczyt kolumny A bokiem księżyc występował młody Jako atłasu brzeg z zamkniętej trumny I była cichość bardzo przepaścista.

Od ziemi lekki tuman mgły powstawał, Od niebios gwiazda czasem spadła czysta, I jakby czyn się gdzieś uroczy stawał, Dobrotliwiało natury oblicze. -
\end{abstract}

(PWsz I, 112)

Kolumna znika z pola widzenia czytelnika w podobny sposób, jakby kartkę z jej ilustracją zacząć składać zakładając jej boki: z jednej strony nadciągnęły chmury, z drugiej pojawił się księżyc, z dołu („od ziemi”) zasłoniła ją mgła, a ostatnią kreskę na tym rysunku nakreślił lot spadającej gwiazdy, oczywiście z góry („,od niebios”) na dół. Nie dziwi zatem porównanie do zamkniętej trumny, gdyż kolumna została zasklepiona przez zjawiska kosmiczne i przyrodnicze, tak jak i nie zaskakuje stwierdzenie o ,natury” obliczu, mimo że rozmowa Napoleona z Cezarem odbywała się, jak dowiedzieliśmy się na początku, w „mieście gwarnym”. Nie przekonuje mnie interpretacja tej sceny Zygmunta Dokurny, że „Zwykła, codzienna natura pokrywa czyny historyczne, sama nie ulegając zmianie”, jak i konstatacja, że „czyny nawet największych ludzi w obliczu przyrody powszednieją"19. Przychylam się natomiast do hipotezy Anny Kadyjewskiej,

\footnotetext{
${ }^{18}$ Paralela działania Juliusza Cezara i Napoleona rozpoznana w polskiej tradycji romantycznej ujawnia się także w odzie Hugo, À la colonne, s. 333:

$\mathrm{Ah} !$... comme ce Romain qui remuait la terre,

Vous portez, ô Français ! et la paix et la guerre Dans le pli de votre manteau.

${ }^{19}$ Z. DoKURnO, Przyroda $w$ lirykach Norwida, ,Zeszyty Naukowe UMK: Nauki humanistyczno-społeczne", 1957, z. 2, s. 133-134.
} 
która stwierdziła, że „po odbytej u szczytu kolumny rozmowie w naturze zachodzą pewne zmiany" ${ }^{20}$, bowiem na proces metamorfozy wskazuje w tym fragmencie zarówno ostatni wers: „Dobrotliwiało natury oblicze”, jak i człon porównania: ,jakby czyn się gdzieś uroczy stawał”. W pełni do głosu dochodzi jednak ten wątek w następujących frazach zakończenia: „Więc nikło jedno - drugie się nieciło”, „Cały się rzeczy rytm przelewał w inny”. Warto zauważyć, że sugestie mającej zajść odmiany tkwiły w poprzedzających fragmentach, które mówiły o „rozłagodzeniu”, niebędącym co prawda zapowiedzią tak nagłej i spektakularnej odmiany jak „blask” czy „promień”, lecz podpowiadającym odnowę taką, jak „życia drugiego poczęcie”. Kolumna Vendôme niosła wraz z samą sobą bohatera ziemskiej chwały i wyraziciela mocy. W tej odmianie postaci świata, która zachodzi, brąz czynów pozostał - stał się na powrót - brązem, a wartość „mocy” została pomniejszona, bo zdaje się mieć kres, co kłóci się z ideą wiecznej Romy i nieskończonej chwały jej bohaterów. Zdaniem Marii Janion oznacza to, że we współczesnym Norwidowi świecie „rośnie moc dojrzewających ludów, ale i odpowiedzialność moralna każdej jednostki. [...] Przeminą pomniki upamiętniające sławę dawnych mocarzy, ludy podejmą trud wyzwalania się własną mocą i pracą"21. W tym ujęciu brakuje jednak moim zdaniem kluczowego przesłania, o którym pisał Lyszczyna: „obydwaj wiedzą już, że zasadą dziejów jest przemiana owej pogańskiej mocy w chrześcijańską słabość «dziecięcia», w milczenie i w triumf sumienia" ${ }^{22}$. Pozostaje zatem pytanie, gdzie sama kolumna się kończy, gdzie znajduje to, czego szukała? Zakończenie Vendôme podpowiada, że można tej odpowiedzi nie uzyskać: szczyt kolumny, tak jak i ona cała, został przysłonięty przez spektakl natury, nikt nie może więc dostrzec tej nici, na której zawisnął Juliusz Cezar, ani odkryć, gdzie jej początek.

Kadyjewska wskazywała na niejednoznaczność zakończenia, stawiając także pytania o ewentualny pesymizm konotowany przez „czczość”. Wydaje się, że jedną z możliwych odpowiedzi byłoby też stwierdzenie, że natura ostatnim akordem potwierdza prawdę wyrażoną przez Napoleona, skłaniając do jej przyjęcia nie tylko jego pilnego ucznia w trakcie tej nocnej wykładni dziejów, ale i czytelnika. Zakończenie sytuowałoby się w ten sposób najbliżej wniosku Kadyjewskiej o „zbliżeniu dwóch światów, porozumieniu ziemi z niebem,"23. Alicja Lisiecka wskazywała na „moralno-reformistyczny” charakter kategorii czynu w przeko-

\footnotetext{
${ }^{20}$ A. KADYJEWSKA, Norwidowskie rozmowy umarlych, s. 291.

${ }^{21}$ M. JANiON, M. ŻMiGRODZKA, Romantyzm i historia, Warszawa 1978, s. 243.

${ }^{22}$ J. LYSZCZYNA, Dumanie na placu Vendome, s. 308.

${ }^{23}$ A. KADYJEWSKA, Norwidowskie rozmowy umarlych, s. 291.
} 
naniu Norwida w latach czterdziestych i pięćdziesiątych ${ }^{24}$. Takim postulowanym czynem, do którego sygnałem jest aura lekkości i łagodności spowijająca naturę, byłoby „przepalenie globu sumieniem”. Sumienie jawi się jako nośnik „odbicia nieba", jakie powinno owładnąć ziemią, która przecież pożąda tej odmiany, czego symbolem są ,ręce [...] niezamykalne, / Najokropniejszą rozpadłe tęsknotą" wzniesione ku górze.

Jeżeli rozumieć czczość tak, jak w dalszej części cytowanego fragmentu Epimenidesa: „Zbłąkanych kolumn wiele gmachu gdzieś szukało - / I czczo było: czas mijał, pył padał - cóż ży cie?" - trudno byłoby odnaleźć inny niż nihilistyczny wymiar zakończenia. Metafora żeglarska z zakończenia Vendôme zbudowana wokół obrazu ,żagli” i przywołaniu „śpiewu majtków”, nie musi jednak sprowadzać się tylko do symboliki akwatycznej („kapania na przelewie”), jest to przecież obraz morski, w którym siła wiatru odgrywa ważną rolę. Czczość może być rozumiana również jako brak powietrza, próżnia. Takie użycie nie było obce Norwidowi, czego przykładem jest tekst Cywilizacji: „wbiegłem pomiędzy ramiona dwóch żandarmów, którzy odpłynięcia statku strzegli, jako kariatydy dwie czczość powietrza podpierające [...]"25. Powiew służy żeglarzom, dmąc w ich żagle, i choć niekiedy trafia na ciszę, na czczość, to i tak raźniej potem dmie. Zarówno motyw masztu, jak i wspomnianych kariatyd doskonale wpisuje się w rozwijany przeze mnie wątek interpretacji kolumny, która podtrzymuje samą siebie. Kiedy Wiktor Hugo pisał: „Ach, dalszą jest nicości słabość niż potęga”26, wspominając Napoleona, Cezara, Mahometa, Peryklesa ${ }^{27}$, można uzmysłowić sobie, że wieczną chwałę zyskuje nie ten, kto stanął na szczycie kolumny triumfalnej - bo taki posąg łatwo może obrócić się w pył, o czym przekonują dzieje tak pomników starożytnych wodzów, jak i Napoleona oraz współczesnych bohaterów w wielu regionach świata, lecz ten, kto zbliżył się do „Przedwiecznego” fizyczną śmiercią: „Zawsze w śmierci się imię Bóg do królów zbliża” ${ }^{28}$. Czczość, mimo że bliska nicości, może zatem ocalać wartości, których przeznaczeniem jest wieczne trwanie, a nie oszałamianie ciężarem brązu.

${ }^{24}$ A. LISIECKA, Z problemów historyzmu Cypriana Norwida: na marginesie tomu 7 „Pism”, „Pamiętnik Literacki” 50(1959), z. 2, s. 369-370.

${ }^{25}$ C. NorwID, Cywilizacja (PWsz VI, 48).

${ }^{26}$ V. Hugo, Les Feuilles d'automne, IV, [w:] TENZE, Euvres complètes. Poésie, t. II, Paris 1837, s. 487:

„Hélas! plus de grandeur contient plus de néant!

La bombe atteint plutôt l'obélisque géant

Que la tourelle des colombes".

${ }^{27}$ Tamże: „Napoléon, César, Mahomet, Périclès, / Rien qui ne tombe et ne s'efface!”

${ }^{28}$ Tamże: „C'est toujours par la mort que Dieu s'unit aux rois; [...]”. 
Kategorie czynu i dobroci, która wraz z jego spełnianiem zaczyna stawać się dominantą pejzażu, rozpatrywane są w napisanym w tym samym roku „trzecim” liście o emigracji Norwida: „Szanuję też wszystko nieobłudnie, co ofierniczego, tajemnego w boleściach się Polski zanieciło. Ale byłoby brakiem wiary w naród - ale byłoby patriotyzmem chorobliwym nie orzec otwarcie, iż tych rzeczy do codziennych kwestii się nie mięs za, ale się z nimi łączy tylko, i to przez dobrego uczynienie" (PWsz VII, 24).

\section{ODSŁONA DRUGA. „RZYM, PAN NA ZIEMI, KONA I SZALEJE”}

W wierszu Vendôme to ludzie uosabiali proces kontynuacji czynu historycznego, poprzez dialog wyrazicieli dwóch epok, rozmowę Cezara i jego duchowego syna. Z kolei w Odpowiedzi do Włoch tę ciągłość symbolizuje materia: kolumna na placu Vendôme jest kolumną starożytnego Rzymu, która została „przebrązowana" na imię innego z władców, na imię Napoleona. Wielość architektonicznych elementów nawiązujących do starożytnych wyobrażeń i budujących przestrzeń Vendôme została zaś tu zamieniona w szereg postaci, oddających klimat tej paraleli między antycznym Rzymem a dziewiętnastowiecznym Paryżem: Irydion i Masynissa, pretorianie i sądzony Jezus, a także Słowianin. Jak zauważył Piotr Chlebowski, ,wiersz ciąży ku maksymalnej kondensacji; motywy i symbole są tu jak barwne plamy rzucane przez artystę na czyste płótno, a ledwo zarysowane ich kontury dozwalają jedynie na zbliżenie, skrót przy jakiejś próbie dokładniejszego opisu ze strony odbiorcy" ${ }^{, 2}$. Czytelnik może podjąć próbę zrozumienia wymowy wiersza przede wszystkim uzupełniając tekst o czasowniki, które zostały bardzo oszczędnie rozmieszczone w niektórych fragmentach: $\mathrm{w}$ zwrotce drugiej $\mathrm{w}$ zdaniu pytającym, $\mathrm{w}$ trzeciej $\mathrm{w}$ zdaniu podrzędnym okolicznikowym przyczyny oraz czwartej - w ostatnim zdaniu wiersza. Wiele zatem motywów jest $\mathrm{w}$ istocie pozostawionych samych sobie, $\mathrm{w}$ tym także interesująca mnie kolumna:

Tu - w Rzymie tym - och! w Rzymie...

Gdzie przebrązowana,

$\mathrm{Na}$ Napoleona wielkie imię,

Kolumna Trajana -

(PWsz I, 184)

\footnotetext{
${ }^{29}$ P. Chlebowski, , Odpowiedź do Włoch... (Fraszka)”, [w:] Norwidowskie fraszki (?), red. J. Leociak, Warszawa 1996, s. 130-131.
} 
Kolumna w Rzymie wznosi się, stoi, zachwyca, po prostu jest? Wymieniona jako jeden z kilku obiektów w pierwszej strofie (obok miecza, pancerza i katakumb), osadzona w realiach antycznych, nie domaga się verbum tak mocno, jak w przypadku początku drugiej strony, gdzie brak czasownika wpływa na wieloznaczność fragmentu:

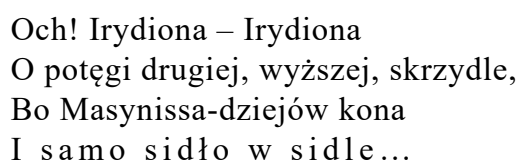

Chlebowski dostrzega w tym „wezwanie”, ${ }^{30}$, wskazując, że potrzeba innego niż ten, którego atrybutem był „krótki miecz”. Inaczej interpretuje ten fragment Grażyna Halkiewicz-Sojak, pokazując, że strofa trzecia kontynuuje zdarzeniowość drugiej: „»Że zwy ciężyłeś, Panie... «najduje składniowe dopełnienie w III zwrotce: »[zwyciężyłeś] Irydiona« oraz »[zwyciężyłeś] Bo Massynisadziejów kona«"31.

Przywołaniu kolumny towarzyszy w utworze Norwida przypis: jeden spośród dwóch, które zaczynają się od „wiadomo”. Wymienienie nazwy „kolumna Trajana" w tekście wiersza i ewokacja postaci Napoleona uwypukla obiektywny charakter tej uwagi - kolumna nie „przypominała”, nie mogło się „wydawać”, lecz kopią jest i jako taka była zamierzona, co poświadczają relacje z etapów jej projektowania i wykonania $^{32}$. Ta hipoteza zyskuje na znaczeniu, jeżeli rozpatrzyć także drugi przypis. Nie może tkwić u źródła chęci objaśnienia sam fakt podkreślenia ścisłości pokrewieństwa architektonicznego kolumny z placu Vendôme z kolumną Trajana, skoro w tym samym zdaniu zostaje też wskazana kolejna, „Antoniuszowa” - być może ważniejsze jest zatem odniesienie się do samego

${ }^{30}$ Tamże, s. 129.

${ }^{31}$ G. HALKIEWICZ-SoJaK, [Wokół interpretacji], [w:] Norwidowskie fraszki (?), s. 139.

${ }^{32}$ D. Rowell, Paris: The 'New Rome' of Napoleon I, s. 68-69: „Most recommendations opt for a triumphal structure reminiscent of Trajan's Column: one such proposal envisages an exact copy, with the addition of certain modifications enduring absolutely that the glorious actions of Napoleon, rather than those of Trajan, be the focus of the monument and its decoration! Although the Colonne de la Grande Armée [...] differed slightly to the earlier proposal $[\ldots]$, the monument's relationship with Trajan's Column was certainly no less explicit. The architects of this splendid Napoleonic structure [...] worked under the direction of Denon. While the Emperor was also directly involved in the project, Denon played a salient role, especially in relation to the finished structure's affinity with Trajan's Column". 
czerpania z rzymskiej tradycji honorowania wodzów ${ }^{33}$. Kolejną przyczyną, dla której Norwid zdecydował o umieszczeniu tego przypisu, mogłaby być wola podkreślenia, że jest „kopią”, co współgra z wnioskami Halkiewicz-Sojak co do epitetu „przebrązowana”, który zdaniem badaczki: „Wywołuje skojarzenia $\mathrm{z}$ analogicznymi konstrukcjami słowotwórczymi: przepisana, przerysowana, przenicowana... i w jednym słowie streszcza wtórność, fałszywy blask cezariańskich aspiracji Paryża połowy XIX wieku"34. Jednak w zamyśle architektów fakt, że sięgnięto do tego pomysłu i wprowadzono pewne modyfikacje, miał podkreślać prymat pierwszego cesarstwa nad Rzymem cezarów ${ }^{35}$.

Na podstawie tekstu nie można odpowiedzieć na wyjściowe pytanie, czego szuka kolumna, choć niesie ze sobą nazwisko tego, który szykuje zamach stanu. Pożądanie „potęgi drugiej, wyższej” oraz „mocy drugiej, młodzieńczej”, 36 wpisuje jednak ten utwór w próby powiązania tych wartości z obrazem kolumny triumfalnej. Wnioski wydają się być tożsame $\mathrm{z}$ tymi już przedstawionymi w zakresie rozumienia mocy - moc musi wznieść się do innych wartości niż tylko „zewnętrzne oznaki siły, zasłaniające rzeczywistą słabość, twórczą niemoc i wewnętrzny rozkład kulturowy, ${ }^{37}$. Edward Kasperski wskazywał na zbieżność wniosków płynących z rozumienia tego wiersza z IV lekcją O Juliuszu Słowackim w zakresie „, archistrategii dziejów”, ${ }^{38}$, warto też dodać, że omawiając „drugiej potęgi osie" Norwid zauważał, że dla Francji są nimi „własne rewolucje” (PWsz VI, 436). W pisanym w 1872 r. po zburzeniu kolumny Vendôme w czasie Komuny Paryskiej szkicu Obywatel Gustaw Courbet notował: „Federacja Artystów Paryskich powstaje z rewolucji 18-o marca. - Kolumna Vendôme roztrzaskana jest o bruk placu 16-o maja" (PWsz VI, 491). Są to dwa wydarze-

\footnotetext{
${ }^{33}$ Dwie wymienione kolumny łączy fakt, iż na ich szczycie zamiast imperatorów postawiono postacie świętych: ,Jeżeli [...] wzrok nasz dalej puścimy, za Kapitol i za wąskie dzisiejszego Rzymu uliczki, stają nam wysoko ponad szczyty świątyń dwie spiżowe postacie apostołów, na pogańskich postawione kolumnach. Święty Paweł stanął z mieczem w ręku jako zdobywca ziemi na kolumnie, którą niegdyś zdobił posąg Marka Aureliusza, święty Piotr z kluczami w ręku, jako zdobywca nieba, spoczął na słupie, co ongi nosił Trajana. W tych dwóch kolumnach, wymowny jest obraz stosunku chrześcijaństwa do rzymskich dziejów, które wprawdzie zwyciężyło, ale zwyciężyło tym łatwiej, że się oparło na potędze państwa Trajanów i Marków Aureliuszów (K. CHŁĘDOwSKI, Szkice z Włoch, „Przegląd Polski” 8(1873), z. 1, lipiec, s. 37).

${ }^{34}$ G. HALKIEWICZ-SOJAK, [Wokół interpretacji], s. 141.

${ }^{35}$ Kolumna Vendôme była wyższa, przedstawiała współczesne wydarzenia oraz odtwarzała realia, zob. D. Rowell, Paris: The 'New Rome' of Napoleon I, s. 70-71.

${ }^{36}$ Por. P. ChleBowsKi, ,Odpowiedź do Wtoch... (Fraszka)”, s. 131.

${ }^{37}$ Tamże, s. 125.

${ }^{38}$ E. KASPERSKI, Dyskursy romantyków. Norwid i inni, Warszawa 2003, s. 133.
} 
nia, które złożyły się na proces „dojrzewania na słońcu” „arcywielkiego jakiego skandalu”, dzięki któremu obnażone zostało „zatracenie duszy człowieczej”, tego „cywilizacji rezultatu!”, jakim było wysoka ocena niektórych krytyków nieodpowiadająca faktycznemu przesłaniu dzieł Courbeta. Upadek kolumny wyznacza zatem koniec pewnego rozdziału w życiu tego twórcy ${ }^{39}$, ale Paryż w szkicu Norwida uwidacznia się jako miasto wstrząsane odmianami dziejowymi i doświadczone w procesie odbudowy tego, co zburzone,przedstawia obraz: „wielkiego miasta nawiedzanego żądzą barykad, ale umiejącego się odbudowywać z równą zniszczeniu energią" (PWsz VI, 485).

\section{ODSŁONA TRZECIA. \\ ZAMIAST LOURDES, ROME, PARIS - PARYŻ, RZYM, PAESTUM}

Wśród omawianych Norwidowskich świadectw legendy cesarza Francuzów tekstem najbliższym emocjonalnej odzie Wiktora Hugo dedykowanej kolumnie na placu Vendôme jest zaledwie czterowiersz pochodzący z poematu Szczesna. Utwór autora Hernaniego został po raz pierwszy opublikowany 9 lutego $1827 \mathrm{r}$. na łamach „Journal des Débats”, a był odpowiedzią na zdarzenie, do którego doszło w styczniu tego samego roku w ambasadzie austriackiej w Paryżu. Czterech zaproszonych marszałków zostało wtedy zaanonsowanych bez tytułów nadanych im przez Napoleona ${ }^{40}$. Oda jest oceniana jako intymne wyznanie, w którym z egzaltacją oddaje się cześć Napoleonowi, ale także zachłannie czerpie się przekaz historyczny, który sama sobą przedstawia kolumna ${ }^{41}$. Poeta nazywa ten zabytek ,ruiną triumfalną” (epitet przynależny kolumnie intrygująco przedstawia się, towarzysząc elementowi przestrzennemu, który poświadcza przemijanie i upadek) oraz opowiada, że nigdy jeszcze cudzoziemiec w cieniu kolumny nie

\footnotetext{
${ }^{39}$ Skandal, o którym pisze Norwid, dotyczył właśnie pewnego wydarzenia związanego z kolumną Vendôme. Courbet został członkiem rady Komuny 16 kwietnia 1871 r., podczas gdy dekret o zburzeniu kolumny wydano już 12 kwietnia. Fakt, że został on kontrasygnowany przez Courbeta, jego obecność na miejscu egzekucji tego dekretu oraz szereg innych okoliczności i wypowiedzi przyczyniły się do tego, że zapadł wyrok oskarżycielski o ukaranie grzywną, co spowodowało, że Courbet spędził resztę życia na wygnaniu.

${ }^{40} \mathrm{~J}$. Cousin, Napoléon I ${ }^{\text {er }}$ dans l'œuvre de Victor Hugo avant l'exil, [w:] Mélanges de littérature, philologie et histoire offerts à Louis Arnould, Genève 1973, s. 122.

${ }^{41}$ A. LAVERnHe-Grosset, "Cela vaudra-t-il la peine d'être lu? Cela sera-t-il lu?», [w:] Envois et dédicaces, éd. Gérard Farasse, Villeneuve d'Ascq 2010, s. 102: „L'intensité du manque et la voracité de cette lecture attachent la mémoire dépossédée du poète au déroulement imaginaire des bas-reliefs, comme une bouche avide aspire à se remplir. [...] Les yeux éblouis par la colonne en mouvement, le poète réveille la Grande Armée [...]”.
} 
przeszedł, nie drżąc z przerażenia. Zacytujmy zatem epistolograficzną relację Szczesnego, Polaka w Paryżu:

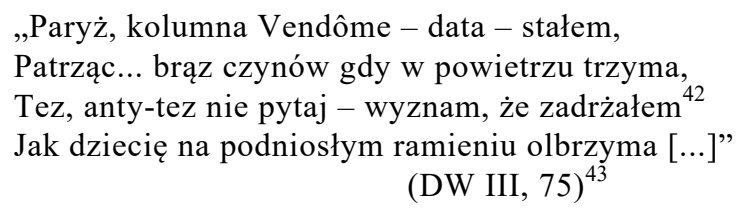

Poznanie paryskiej kolumny to odmienny rodzaj doświadczenia Szczesnego niż ten na wcześniejszym etapie niemieckim (,chodzę na kursa filozofii”) oraz późniejszym rzymskim, który chcąc przedstawić analogicznie do paryskiego, w miejscu ,stałem, patrząc” można by powiedzieć: „ukląkłem, modląc się”:

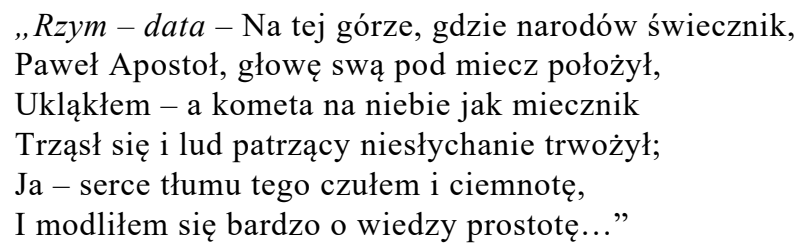

(DW III, 75)

Inaczej niż w innych pismach Norwida, nie dostrzegamy w tych fragmentach, w tych dwóch następujących po sobie strofach poematu, próby paraleli obrazu dwóch miast, prób zunifikowania ich czy uwypuklenia kontynuacji między rzymskim i francuskim dziedzictwem. Stanowią one raczej opis dwóch następujących po sobie na skali czasu i w wymiarze przestrzennym zdarzeń, akcentując wielorakość doświadczeń będących udziałem bohatera. Mimo to zarówno w warstwie formalnej (stylizacja epistolograficzna na dość konwencjonalny nagłówek listu, podanie miasta i daty, kiedy kieruje się przesyłkę), jak i w sposobie obrazowania (porównania ,jak”: ,jak dziecię”, ,jak miecznik”) można znaleźć argument za zestawieniem tych dwóch refleksji urbanistycznych, poszukiwaniem ekwiwalencji ich motywów. Rozpoczynając taki eksperyment, można zasugerować, że z ekscerptu paryskiego listu przebija ruch ku górze, w rzymskich refleksjach natomiast ku ziemi. Przed kolumną Vendôme bohater stoi i szuka jej wzrokiem, co implikuje (biorąc pod uwagę 44 metry jej wysokości) wzniesienie

\footnotetext{
${ }^{42}$ Por. V. Hugo, À la colonne, s. 334: „l'étranger t'admire avec effroi; Jamais, ô monument, $[\ldots]$ Les étrangers sans peur n'ont passé sous ton ombre".

${ }^{43}$ Por. V. Hugo, À la colonne, s. 333: ,[...] de tout ce qu'a fait une main colossale, / Seul es resté debout; — ruine triomphale / De l'édifice du géant!"
} 
głowy ku górze, w przypadku doświadczeń rzymskich natomiast to kometa zwraca uwagę patrzących, ale, co wydaje mi się istotne, nie jesteśmy pewni, czy wśród nich jest bohater, to lud jest „patrzący”, a Szczesny - być może pochylił głowę w modlitewnej refleksji? Zmysł, dzięki któremu jednoczy się z widzami kosmicznego spektaklu, to „serce”, zatem raczej współczuje on z nimi niż widzi to samo. Kolejny taki antynomiczny przykład z omawianych dwóch strof to rodzaj pewnego gestu, który jest opisywany w drugim wersie następujących po sobie strof: w Paryżu kolumna utrzymuje brąz czynów w powietrzu, z kolei w Rzymie „Paweł apostoł, głowę swą pod miecz położył”. Czasowniki „trzymać” i „położyć” uwypuklają różnice między czynem, którego reifikacją jest paryska kolumna a czynem-męczeństwem Pawła Apostoła, między jednostkowością czynu, jego dokonaniem, a niedokonaniem trwania. Wprowadzenie kategorii czynu oznacza wzbogacenie dotychczasowego repertuaru Norwidowskiej myśli o kolumnie triumfalnej, wyłaniające się już w słowach o „dobrym uczynieniu": nie tylko moc i potęga, ale zapis działań na arenie historii znajdują swój wyraz poprzez kolumnę. Nieprzypadkowo używam słowa „zapis”, ponieważ tak jak średniowieczne eposy, określane chansons de geste, głosiły chwałę bitewnego zgiełku cesarstwa Karola Wielkiego, tak reliefy na kolumnach triumfalnych starożytnego Rzymu, układane w spiralny ciąg, opowiadały historię zwycięstw imperatorów (res gestae). Jednakże istnieje także druga, jak sądzę, możliwość interpretacji fragmentu poświęconego Rzymowi, dzięki dopowiedzeniu o rzymskim wzgórzu usytuowanemu zaraz po dacie włoskiego listu - być może należy je potraktować jako odpowiednik nie grupy „brąz czynów”, a określenia „kolumna Vendôme", jako swoiste dookreślenie lokalizacji, której pozornie brakuje (jest przecież „Paryż, kolumna Vendôme, data”, ale — tylko „Rzym - data”). W tym przypadku peryfraza „brąz czynów” odpowiadałaby obrazowi rzymskiej komety (co zbliża ten fragment do wiersza Vendôme, gdzie widokowi kolumny towarzyszą spadające gwiazdy). Jeszcze jednym ważnym elementem jest człon porównania „Jak dziecię na podniosłym ramieniu olbrzyma”, który z kolei wskazuje na inne umiejscowienie patrzącego niż w wierszu Vendôme, gdzie mowa o „śmiertelnym, co pogląda z ziemi”. O ile jednak w przypadku tego wiersza rozpatrujemy postać być może niespiesznego spacerowicza po mieście nad Sekwaną, jednostki, to nawiązanie do Bernarda z Chartres ${ }^{44}$ w poemacie Szczesna wskazuje na wypowiedź będącą głosem nowożytnych pokoleń.

${ }^{44}$ S. Wielgus, Z badań nad średniowieczem, Lublin 1995, s. 13: „Jesteśmy karłami, którzy wspięli się na ramiona olbrzymów. W ten sposób widzimy więcej i dalej niż oni, ale nie dlatego, ażeby wzrok nasz był bystrzejszy lub wzrost słuszniejszy, ale dlatego, iż to oni dźwigają nas w górę i podnoszą o całą gigantyczną wysokość". 
Warto jeszcze dodać, że określeniem osłabiającym moją hipotezę o innym kierunku ruchu w tych dwóch fragmentach jest wskazówka: „na tej górze, gdzie narodów świecznik". W powieści Korynna, czyli Włochy Anne-Louise Germaine Staël, wchodzącej w skład grupy utworów kształtujących obraz Włoch w epoce romantyzmu, Rzym, dzięki obecności kolumn i wież, wydaje się miejscem stworzonym z innej materii niż ziemskie miasta:

Wszystkie te wzgórza, ich boki i szczyty, gęsto są najeżone dzwonnicami, obeliskami, kolumnami, wieżycami. Nad niemi panuje kolumna Trajana, druga Antonina, trzecia ta, z której jak wieść niesie Neron pożarowi Rzymu się przypatrywał, a nad tym wszystkim poważna ś. Piotra kopuła, dumną podnosi głowę. Rzekłbyś jakieś nadpowietrzne miasto nad tym poziomem do nieba się wznoszące $^{45}$.

Po niemieckim kursie filozofii dopiero w Paryżu Szczesny pojmuje, że stawiał nieodpowiednie pytania: „Tez, anty-tez nie pytaj" "46, a w Rzymie zaczyna pożądać „prostoty wiedzy”, którą opisać można by słowami z Quidama:

\section{$[\ldots]-$ Lud jest zawsze może}

Na równi z wiedza, chociaż jej nie sprosta

Wypowiedzeniem, ni pojąć jej może,

Lecz drgnieniem serca jednym wie, co ludzie

W umiejętności otrzymują trudzie.

(DW III, 227)

Jak podkreśla Magdalena Woźniewska-Działak, dopiero w Rzymie ujawnia się „prawdziwie inicjacyjny charakter” podróży Szczesnego ${ }^{47}$. Taka interpretacja powoduje, że w Szczesnej obraz Rzymu i Paryża może się okazać odmiennym niż w Odpowiedzi do Włoch, gdzie jak zauważyła Magdalena Karamucka, „W kontekście całego utworu przypisywana Rzymowi cywilizacja rozumu, kontynuowana wedle Norwida między innymi przez XIX-wieczny Paryż, zostaje wyraźnie poddana krytyce" ${ }^{48}$. Tutaj klarowny wydaje się podział na fizyczną

\footnotetext{
${ }^{45}$ G. DE STAËL-Holstein, Korynna czyli Włochy, Warszawa 1857, s. 22.

${ }^{46}$ Kontekstem mogą być słowa $\mathrm{z}$ „trzeciego” listu o emigracji: „Filozofia niemiecka, w krytycyzmu swego samowładztwie ułożywszy przeszłości ciąg logiczny i orzekłszy, gdzie się zatrzymała, nie obowiązując do niczego prócz do książki zamknięcia: «Tak - powiada musiało być koniecznie i tak się też koniecznie stało»" (PWsz VII, 25).

${ }^{47}$ M. Woźniewska-Działak, Poematy narracyjne Cypriana Norwida, Kraków 2014, s. 54.

${ }^{48}$ M. KARAMUCKA, , Upiorny” Rzym Norwida, w: Od Syberii po Ameryke. Geografia wyobrażona polskich romantyków, red. A. Kołos, T. Ewertowski, K. Szmid, Poznań 2013, s. 52.
} 
potęgę, który przewyższa rozumowe jej zrozumienie, oraz znajomość serca instynktownie pojmującego prawdy historyczne.

Kontynuując podróż po Italii, Szczesny odwiedza Paestum, w którego opisie, pomimo wyraźnej wzmianki o trzech zachowanych tam świątyniach, brakuje motywu kolumny. Badacz tego tematu powinien jednak pozostać czujnym przy relacji dotyczącej przeszukiwania gruzowiska, gdyż pewien rodzaj gestu tam przedstawionego może kojarzyć się z zadanym przeze mnie na początku pytaniem - co i jak wspiera kolumna:

Każdy klnie, modli się, próżnuje, pości,

Lub złamki bogów z gruzów wydobytych

Na wpółżebrzącej wyciągnąwszy dłoni,

Do podróżników odzywa się sytych -

Stu pieniądz rzuca, żaden łzy nie roni! ...

(DW III, 76)

Domyślać się możemy, iż fragmenty tych posągów, „złamki bogów”, skoro mieszczą się na ludzkiej dłoni, były o wiele mniejsze od tych umieszczanych na kolumnach. Taki pomnik w pomniejszeniu nie został jednak wyniesiony na kolumnę triumfalną, lecz wydobywa go z zapomnienia ręka, negatywnie, bo stereotypowo raczej przedstawionego człowieka Południa ${ }^{49}$, południa Włoch, ta ręka

\footnotetext{
${ }^{49}$ Może też uwydatniać fakt, że Szczesna jest bardziej „satyrą obyczajową” niż jednokierunkowym ironicznym autotematyzmem „,satyry na damę serca”, o czym pisała Zofia Stefanowska (Norwid a poemat dygresyjny, [w:] TAŻ, Strona romantyków. Studia o Norwidzie, Lublin 1993, s. 150). Zwraca moją uwagę również interpretacja Gomulickiego, który odczytywał cytowane przeze mnie w tekście głównym fragmenty poematu, odnosząc je do postaci Szczesnej, co prowadziło jednak do następujących wniosków: „najpełniejsza charakterystyka Szczesnej oraz najpełniejsza historia jej stosunku do kochanka ukazane są nie bezpośrednio, ale właśnie [...] w «gamie-reakcyj-epistolarnych» podróżującego Szczesnego" (C. NoRWID, Dwa poematy miłosne, oprac. i wstępem opatrzył J.W. Gomulicki, Warszawa 1966, s. 25). Zdaniem badacza: „Dość też trochę uważniej przeczytać zacytowane w poemacie urywki listów bohatera, aby z pierwszego z nich dowiedzieć się o jego smutku, zawinionym zapewne przez ukochaną; z drugiego o uświadamianej sobie przez niego biegunowej odmienności jej charakteru; z trzeciego - o cechującym ją braku prostoty (?) [...]”. Berliński kurs filozofii miałby zatem być odpowiedzą na stan ducha wywołany wyłącznie przez relację $\mathrm{z}$ ukochaną, paryskie pytania o tezy i antytezy skrywałyby tajemnicę osobowości Szczesnej, a modlitwa o prostotę wynikałaby z jej braku zauważonego w postaci tej bohaterki. Piąty list z Paestum dotyczyłby w optyce Gomulickiego „,fatalnych znamion niewoli (w jej przypadku: niewoli konwenansu i w ogóle starego obyczaju)" sądzę, że mamy tu do czynienia ze zbytnim zawężeniem znaczenia kierowanych uwag do diagnozy postawy bohaterki. Takie rozpoznanie u Szczesnego rzeczywiście się odbywa, ale we fragmentach innych listów, raczej w tych, które rozpoczyna on od „Zinąd” - miejsce (jego nieokre-
} 
wyciąga go i daje podporę, aby antyczne bóstwo ujrzeć mogli wędrowcy południowych Włoszech, spełnia rolę wyniesienia. Kontemplacja podróżnych nie przypomina jednak doświadczenia Szczesnego, który patrząc na brąz czynów na placu Vendôme, dosłownie zadrżał przeniknięty zachwytem nad ogromem wiedzy, którą można posiąść na takim kursie historii, w Peastum zaś nikt nie zaznał wzruszenia $^{50}$. Przyczyna tej odmiennej reakcji może tkwić w różnym uposażeniu Szczesnego i pozostałych podróżnych, on nie jest „syty”, a jak zauważyła Magdalena Woźniewska-Działak ,ruina Paestum to przede wszystkim ruina zdegradowanej społeczności, która spotyka się od czasu do czasu z sytym przechodniemprzybyszem” wid, jest tylko zapłata. Gest opisany przeze mnie powyżej znajduje jeszcze jedno zastosowanie na końcu utworu, kiedy to dotyczy procesu twórczości literackiej:

Ku czemu lepszą powieść z czasem zrobię, Morał wykażę jasno jak na dłoni, A jaki taki grubą łzę uroni.

(DW III, 78)

Porównanie ,jak na dłoni” odsyła do gestu przeszukiwaczy ruin, czytelnik wykazałby się jednak w przeświadczeniu Norwida większym zrozumieniem w lekturze niż turyści postawieni wobec doświadczenia zanikających śladów dawnych cywilizacji.

Podsumowując wnioski płynące z interpretacji Szczesnej, warto zauważyć, że w tej triadzie Paryż - Rzym - Paestum (od Północy, czy też, jak ujął to Edward Kasperski, od „północnego Rzymu”, ${ }^{2}$ przez Rzym właściwy po Południe) został zawarty obraz jednej tylko kolumny, kolumny Vendôme w Paryżu, natomiast możemy znaleźć inne gesty powielające moim zdaniem ten motyw. Odpowiedzią na zadane na początku przeze mnie pytanie jest odpowiednio: czyn - czyn męczeński / zjawisko kosmiczne - wydobyty z ruin fragment posągu, pełniący funkcję atrakcji turystycznej oraz w sensie metaforycznym morału.

śloność) ustępuje wtedy bohaterce, aby to jej cechy, odkrywane stopniowo przez Szczesnego, mogły się pojawić na horyzoncie znaczeniowym tekstu.

${ }^{50}$ Dziewiętnastowieczny obraz Paestum oczyma Herberta nie odbiega znacząco od wizji Norwidowskiej, pojawiają się w nim: przewodnik, turyści, gest ręki i brak emocji: „[...] teraz snują się tu wycieczki, przewodnik beznamiętnym głosem podaje wymiary świątyni z dokładnością buchaltera. [...] Wskazuje ręką ołtarz, ale ten porzucony kamień nikogo nie wzrusza" (U Dorów, w: TENŻE, Barbarzyńca w ogrodzie, Warszawa 2004, s. 34-35).

${ }^{51}$ M. WoźNIEWSKA-DZIAŁAK, Poematy narracyjne Cypriana Norwida, s. 55.

${ }^{52}$ E. KASPERSKI, Dyskursy romantyków, s. 132. 


\section{ZAKOŃCZENIE}

Jeżeli po powyższej analizie może się wydawać, że temat wartości niesionych przez kolumnę Vendôme w zderzeniu z kulturą Rzymu nie został dostatecznie oświetlony, przyczyna tkwić może w Norwidowskiej intencji uczynienia niedostatecznie jasnym tego zagadnienia. Tych, którzy chcieliby zrozumieć przesłanie z początku $U$ kolebki narodu, Norwid przestrzegał, że nie będzie łatwo go dociec: „Ale zbliżenie tych dwóch rzeczy, to jest fragmentów rzeźby starożytnej, kartek Lelewela i Byrona listów, ten tylko zrozumie, kto wiedzieć by mógł, że ja inaczej pamiętnika-swojego nie pojmuję, tylko jak najciemniejszy kącik mojej pracowni!” (PWsz VII, 229). Wspomniana rzeźba starożytna to „na-pół-rzeźby kolumny Trajana”, a listy Byrona „z Włoch i z Grecji pisane o tym i owym, i o losach świata i narodów, i literatury, i serc ludzkich mówiące pobieżnie - łatwo - nieledwie przypadkowo" - i starożytne reliefy, i byronowskie nastroje dziewiętnastowiecznych niespokojnych wędrowców napotkaliśmy w powyższej interpretacji.

Kolumna Vendôme osadzona jest w realiach współczesnych Norwidowi, to dziewiętnastowieczny człowiek ogląda ją i interpretuje, ale wprowadzona przez autora relacja $\mathrm{z}$ Italią pozwala na odniesienie jej dziedzictwa do przeszłości. Są to związki wielorakiego rodzaju - w Vendôme Paryż odwiedza gość z antycznego Rzymu, dojrzalszy o doświadczenia Napoleona, ale i tak wysłuchujący jego wykładu; w Odpowiedzi do Włoch sytuacja miasta nad Sekwaną opisywana jest kategoriami znanymi z realiów epoki krzewienia się chrześcijaństwa, w Szczesnej wreszcie doświadczenie Paryża i Rzymu, a także południowych Włoch, pozwala ukazać galerię postaw ludzkich - próby rozumowego pojęcia, modlitwy o pokorę serca i prostotę wiedzy, rolę ludzkiego współodczuwania. W każdej z tych odsłon kolumna to jednak lekcja - dla bohaterów: Juliusza Cezara, Szczesnego - oraz dla odbiorców poezji Norwida, jak w Odpowiedzi do Włoch - i jest to lekcja uniwersalna, dotycząca potęgi, która powinna tak dla władców panujących na ziemi, jak i jej mieszkańców - przekształcić się w potęgę duchową, pozwalając dobrze sprawować rządy oraz przywrócić rolę współczucia w ludzkim doświadczeniu.

\section{BIBLIOGRAFIA}

Alvey N.M., Strange Truths in Undiscovered Lands: Shelley's Poetic Development and Romantic Geography, Toronto 2009.

BAtTles D., The Medieval Tradition of Thebes: History and Narrative in the „Roman de Thèbes”, Boccaccio, Chaucer, and Lydgate, Routledge 2004.

ChŁĘDowski K., Szkice z Włoch, „Przegląd Polski” 8(1873), z. 1, lipiec. 


\section{MAGDALENA KOWALSKA}

Comay R., Mourning Sickness: Hegel and the French Revolution. Cultural Memory in the Present, Stanford 2010.

Cousin J., Napoléon I Ir dans l'œuvre de Victor Hugo avant l'exil, w: Mélanges de littérature, philologie et histoire offerts à Louis Arnould, Genève 1973.

DoKURno Z., Przyroda w lirykach Norwida, „Zeszyty Naukowe UMK: Nauki humanistycznospołeczne" 1957, z. 2, s. 105-142.

Hegel G.W.F., Esthétique: cahier de notes inédit de Victor Cousin, éd. A.P. Olivier, Paris 2005.

Hugo V., Cuvres complètes. Poésie, vol. I-II, Paris 1834-1837.

JANION M., ŻMIGRODZKA M., Romantyzm i historia, Warszawa 1978.

KADYJEWSKA A., Norwidowskie rozmowy umartych - dialog postaci i epok, w: Liryka Cypriana Norwida, red. P. Chlebowski, W. Torun, Lublin 2003.

KARAMUCKA M., , Upiorny” Rzym Norwida, [w:] Od Syberii po Ameryke. Geografia wyobrażona polskich romantyków, red. A. Kołos, T. Ewertowski, K. Szmid, Poznań 2013.

KASPERSKI E., Dyskursy romantyków. Norwid i inni, Warszawa 2003.

LABOURIEU T., La Colonne Vendôme, roman historique, Paris 1872.

LAVERnHe-Grosset A., "Cela vaudra-t-il la peine d'être lu ? Cela sera-t-il lu ?», [w:] Envois et dédicaces, éd. Gérard Farasse, Villeneuve d'Ascq 2010.

LeB(euf F., Dialogue entre la colonne Vendôme et la colonne de Juillet, Paris 1843.

LisIECKA A., Z problemów historyzmu Cypriana Norwida: na marginesie tomu 7 „Pism” „Pamiętnik Literacki” 50(1959), nr 2, s. 331-421.

LySZCZYNa J., Dumanie na placu Vendôme. Norwid wobec romantycznego kultu Napoleona, w: Norwid-spotkania kultur, red. E. Chlebowska, Lublin 2015.

Norwidowskie fraszki (?), red. J. Leociak, Warszawa 1996.

Rowell D., Paris: The 'New Rome' of Napoleon I, London-New York 2012.

SKILTON D., Tourists at the ruins of London. The Metropolis and the Struggle for Empire, „Cercles” 17(2007), s. 93-119.

Stä̈L-Holstein G. de, Korynna czyli Włochy, Warszawa 1857.

Stefanowska Z., Norwid a poemat dygresyjny, [w:] TAŻ, Strona romantyków. Studia o Norwidzie, Lublin 1993.

Troyes C. de, Cligès, Berlin 2006.

WoźniewsKa-DzIAŁAK M., Poematy narracyjne Cypriana Norwida, Kraków 2014.

WYKA K., Cyprian Norwid: poeta i sztukmistrz, Kraków 1948. 


\title{
KOLUMNA NA PLACU VENDÔME A PRZEMIJAJĄCA POSTAĆ ŚWIATA STAROŻYTNEGO RZYMU W PISMACH CYPRIANA NORWIDA
}

\author{
S t r e s z c z e n i e
}

Artykuł przedstawia motyw kolumny triumfalnej w utworach Norwida: Vendôme, Odpowiedź do Wtoch... (Fraszka), Szczesna. Inspiracji do zadania pytania o funkcje kolumny i jej symboliczną siłę nośną dostarczyła Estetyka Georga Wilhelma Friedricha Hegla, a także fragment Epimenidesa: „Kolumn wiele, [...] Zbłąkanych kolumn wiele, gmachu gdzieś szukało - ". W myśli Norwida wieczną chwałę zyskuje nie ten, kto stanął na szczycie kolumny triumfalnej - bo taki posąg łatwo może obrócić się w pył, o czym przekonują dzieje pomników m.in. starożytnych wodzów i Napoleona, lecz ten, kto zbliżył się do „Przedwiecznego” fizyczną śmiercią. „Moc" jest tą wartością, która nieodwołalnie jest związana z kolumną triumfalną, lecz musi wznieść się do innego wymiaru niż tylko siła fizyczna. W artykule przypomniano także koncepcję Paryża jako „nowego Rzymu”, ożywioną w XIX wieku.

Słowa kluczowe: kolumna; Juliusz Cezar; Napoleon; starożytny Rzym; Paryż; triumf; moc.

\author{
THE COLUMN IN PLACE VENDÔME AND THE FLEETING \\ FORM OF ANCIENT ROME IN THE WRITINGS OF CYPRIAN NORWID
}

S u m m a r y

The article presents the image of a triumphal column in Norwid's Vendôme, Odpowiedź do Wtoch (Fraszka), and Szczęsna. Inspiration to ask a question about the role and symbolic power came from Hegel's Aesthetics and this fragment of Epemenides: "The many columns ... many stray columns sought an edifice..." In Norwid's thought, eternal glory is not for the one who stood atop a triumphal column - such a monument can easily turn into dust, which is shown by the fate of other monuments, such as those of ancient commanders and Napoleonbut the one who comes close to the „Pre-Eternal” upon physical death. The "power" is a value that is irrevocably tied to the triumphal column but has to rise to another dimension, other than physical power. The article recalls the notion of Paris as a "new Rome," revived in the 19th century.

Key words: column; Julius Caesar; Napoleon; ancient Rome; Paris; triumph; power.

MAGDALENA KOWALSKA - doktor nauk humanistycznych w zakresie literaturoznawstwa, autorka książek Prowansja w pismach polskich romantyków (2015) i Litanic Verse III: Francia (2018), pracownik Instytutu Literaturoznawstwa UMK; lena_k@wp.pl. 